\title{
Existing Health Care Management Practices by Farmers of Kanpur Nagar District of Uttar Pradesh, India
}

\author{
Deepak Singh*, Ved Prakash, P. K. Upadhyay, Narendra Kumar, \\ Satendra Kumar and Vimal Kumar
}

Department of Animal Husbandry \& Dairying, Chandra Shekhar Azad university of Agriculture and Technology, Kanpur, (U.P.), India

*Corresponding author

Keywords

Health, Care,

Management,

Dairy, Animals,

Farmers

Article Info

Accepted:

07 January 2021

Available Online:

10 February 2021
A field study was conducted to ascertain the health care management practices followed by dairy animals owners in the Kanpur Nagar district of Uttar Pradesh and data were collected from randomly selected two blocks and 200 farmers through a personal interview with the help of a structured interview schedule. It was recorded that 46.00 per cent of the farmers vaccinated their animals against F.M.D./HS. Most of the buffalo keepers disposed of the placenta by deep-buried 58.50 per cent and only 31.00 per cent of farmers disinfect by tincture iodine and dettol some time use mustard oil. 41.00 per cent of the farmers got their sick animals treated by veterinary doctor, 32.50 per cent by the help of a quack and 26.50 per cent by the VLDA (stockman). More than half 56.00 per cent farmers were facilitating wallowing practices to their buffalo. Only 10.00 per cent of farmers testing for mastitis control. More than half 58.00 per cent farmers were dewormed their milch animals and 72.50 per cent of farmers have not dewormed their calves regularly. Only 31.50 per cent of farmers aware isolate their animal from healthy animals. Only 24.00 per cent of the farmers bury the dead body of animals outside the village.

\section{Introduction}

Dairy farming in India plays an important role in generating income, employment, and improving household nutrition. India has about 535.78 million total livestock population in 2019. The current cattle population in India is 192.49 million which contributes around 35.94 per cent of the livestock population. The current buffalo population of India is 109.85 million which accounts for 20.45 per cent of the livestock population (Livestock census census 2019). Livestock production management practices regarding feeding, breeding, housing, and health care are the most important elements in increasing dairy production. Sometimes, due to some social and local problems traditional managemental practices are common in run their dairy business by the farmers in the village area. Operation flood plays a major role in the country's annual milk production more rapidly, if the dairy animal were properly fed balanced diet and given better 
health care, which has been amply demonstrated in the co-operative network of dairy. Efficient management related to dairy animals is necessary to increase milk production, but it needs a strong database. Livestock is a main source of income; it has obtained significance for its capacity to reduce poverty and unemployment in rural areas. Indian livestock population supplies enormous opportunity to support rural income and speed up the pace of poverty reduction. However, the proper policy is in need of successful capitalization of these occasions that facilitates growth and productivity. Productive dairy animals depend on the quality of nutrition, animal health, and genetic makeup. The use of agricultural by-product is not very frequent. However, the inclusion of dried stoned olive pomace in a ration for lactating buffaloes did not produce any significant difference in terms of milk yield while improving some qualitative parameters (Terramoccia et al., 2013).

Proper health care practices are required to be followed for the maintenance of animals' health, prevention of various diseases, and clean milk production. The dairy animal keepers must have a thorough understanding of the facts that milk production can be increased by the adoption of improved health care practices. The present study was undertaken to ascertain the health care practices of dairy animals followed by dairy animal keepers in the village areas of Kanpur Nagar.

\section{Materials and Methods}

The study was conducted purposively in the central zone of Uttar Pradesh. Kanpur occupies the north-western part of the Kanpur division. The present study was conducted by comprising two different blocks Bilhaur and Kalyanpur of Kanpur Nagar district of U.P. The study area has more buffalo population.
In each block, Ten villages were selected, and also in all these villages ten farmers were selected randomly have a vast opportunity for rural development through buffalo.

Data was collected by the personal interview. A personal interview schedule is considered the most important tool it can get the most authentic first-hand information. A questionnaire (schedule) was developed with help of various places related to animal husbandry and dairying and all that information were collected at the time of the survey. Statistical tools percentage using the methods suggested by Snedecor and Cochran (1994).

\section{Results and Discussion}

It was recorded that 46.00 per cent of the farmers vaccinated their animals against F.M.D./HS while 26.50 per cent of farmers vaccinate their animals against F.M.D./brucellosis followed by 24.00 per cent farmers against H.S./ B.Q. only 03.50 per cent vaccinate against rabies. This finding agreement with Bhagat et al., (2019), Chakravarthi et al., (2017), Divekar et al., (2016), Khadda et al., (2017), Patel et al., (2019b) (Table 1).

It was revealed that most of the buffalo keepers disposed of placenta deep-buried by 58.50 per cent and throw in out skirt by 41.50 per cent farmers. The finding of disposal of placenta recorded in present study are in agreement with the Choudhary et al., (2017a), Godara et al., (2017a), Sivaji et al., (2018). Deep buried is good work for making a healthy environment.

Most of the farmers revealed that 69.00 per cent were not disinfected noval cord of calf and 31.00 per cent farmers disinfect by tincture iodine and dettole some time use mustard oil. This study related to disinfection 
of noval cord is in agreement with Malsawmdawngiana and Rahman (2016), Singh (2018). This disinfection of novel cord is important for calf health but found most of the farmers were not practice.

41.00 per cent of the farmers got their sick animals treated by veterinary doctor, 32.50 per cent by the help of a quack and 26.50 per cent by the VLDA (stockman). This study similar to the Khadda et al., (2017), Patel et al., (2019b), Sabapara et al., (2015a), Viswakarma et al., (2018) observed in the study most of the farmers treated their animals by livestock inspector.

In my study area found that more than half 56.00 per cent farmers were facilitate wallowing practices to their calf and 44.00 per cent not facilitate wallowing practices. These findings are in agreement with Golhar et al., (2017), Kishore et al., (2013), Reddy et al., (2017), Sivaji et al., (2018). Wallowing practice is helpful for maintaining body temperature in summer.

I observed from my study 92.50 per cent of farmers were washed hindquarters after placenta drop but 07.50 per cent of farmers did not wash hind quarter after placenta. This is an important practice for taking clean milk from dairy animals and makes hygiene. This study related washing hind quarter agreement with Godara et al., (2017a), Godara et al., (2018b).

Table.1 Existing health care management practices

\begin{tabular}{|c|c|c|c|c|}
\hline Health practices & Bilhaur & Kalyanpur & Farmers & Per cent \\
\hline \multicolumn{5}{|c|}{ 1. Vaccination of animal against disease } \\
\hline A. FMD / H.S. & 66 & 26 & 92 & 46.00 \\
\hline B. FMD / Brucellosis & 27 & 31 & 53 & 26.50 \\
\hline C. FMD / Brucellosis / B.Q. & 12 & 36 & 48 & 24.00 \\
\hline D. Rabies & 00 & 07 & 07 & 03.50 \\
\hline \multicolumn{5}{|l|}{ 2. Disposal of Placenta } \\
\hline A.Deep burial & 76 & 41 & 117 & 58.50 \\
\hline B. Out skirt common land & 24 & 59 & 83 & 41.50 \\
\hline \multicolumn{5}{|c|}{ 3. Noval cord disinfection of calf } \\
\hline A. Regular practice & 44 & 94 & 138 & 69.00 \\
\hline B. Not Practice & 56 & 06 & 62 & 31.00 \\
\hline \multicolumn{5}{|l|}{ 4. Treatment consultation } \\
\hline A.Veterinary Doctor & 23 & 59 & 82 & 41.00 \\
\hline B.VLDA & 30 & 23 & 53 & 26.50 \\
\hline C.Quack & 47 & 18 & 65 & 32.50 \\
\hline \multicolumn{5}{|l|}{ 5. Wallowing practices } \\
\hline a. Yes & 58 & 54 & 112 & 56.00 \\
\hline b. No & 42 & 46 & 88 & 44.00 \\
\hline \multicolumn{5}{|c|}{ 6. Washing of hind quarters after placenta drop } \\
\hline A. Practice & 85 & 100 & 185 & 92.50 \\
\hline B. Not practice & 15 & 00 & 15 & 07.50 \\
\hline \multicolumn{5}{|c|}{ 7. Mastitis control by the farmers } \\
\hline A. Testing & 07 & 13 & 20 & 10.00 \\
\hline
\end{tabular}




\begin{tabular}{|c|c|c|c|c|}
\hline B. Not testing & 93 & 87 & 180 & 90.00 \\
\hline \multicolumn{5}{|c|}{ 8. Practiced deworming measures in Buffaloes } \\
\hline A.Yes & 68 & 48 & 116 & 58.00 \\
\hline B.No & 32 & 52 & 84 & 42.00 \\
\hline \multicolumn{5}{|c|}{ 9. Practiced deworming measures in calves } \\
\hline A.Yes & 17 & 38 & 55 & 27.50 \\
\hline B.No & 83 & 62 & 145 & 72.50 \\
\hline \multicolumn{5}{|c|}{ 10. Isolate the sick animals from healthy ones } \\
\hline A.Yes & 25 & 38 & 63 & 31.50 \\
\hline B.No & 75 & 62 & 137 & 68.50 \\
\hline \multicolumn{5}{|c|}{ 11. Disposal of dead animals } \\
\hline A.Deep burial & 13 & 45 & 48 & 24.00 \\
\hline B.Dispose in open & 87 & 65 & 152 & 76.00 \\
\hline \multicolumn{5}{|c|}{ 12. Measures adopted to control files/ mosquitoes } \\
\hline A. Smoke of waste grass & 86 & 78 & 164 & 82.00 \\
\hline B. Electric fan & 14 & 22 & 36 & 18.00 \\
\hline \multicolumn{5}{|c|}{ 13. Measures adopt to control tick and mites } \\
\hline A. Manually & 68 & 52 & 120 & 60.00 \\
\hline B. Dusting of insecticide & 32 & 48 & 80 & 40.00 \\
\hline \multicolumn{5}{|c|}{ 14. Treatment of repeat breeding and anoestrus } \\
\hline A. Veterinary doctors & 70 & 93 & 163 & 81.5 \\
\hline B. Not treated & 30 & 07 & 37 & 18.5 \\
\hline
\end{tabular}

It was concluded that only 10.00 per cent of farmers testing for mastitis control and 90.00 per cent were not testing of mastitis control by the farmers. This similar finding agreement with Divekar et al., (2016), Gaikwad et al., (2019), Singh (2018), Singh et al., (2019a).

It was observed that more than half 58.00 per cent farmers were dewormed their milch animals and 42.00 per cent not followed by the farmers. This similar finding of deworming their dairy animals are in agreement with Khadda et al., (2017), Patel et al., (2019b), Singh et al., (2019a) and not supports my finding by Patel et al., (2014), Singh (2018) are not dewormed their milch animals.

Observed in my study that 72.50 per cent of farmers were not dewormed their calves regularly and 27.50 per cent practiced occasionally in calves. Present findings are similar to the results recorded by Choudhary et al., (2017a), Singh et al., (2019a), and highly contradicted by Pata et al., (2019), Mulgu et al., (2019) found mostly farmers deworm their farmers in the study area.

It was revealed that mostly 68.50 per cent of buffalo owners were not isolated from the sick animal from healthy ones whereas the remaining 31.50 per cent of farmers aware isolate their animal from the healthy animals. This finding related to isolate their sick animals supports by Chakravarthi et al., (2017), Patel et al., (2019b), and this practice related to isolate sick animals contradicted by Khadda et al., (2017). Disposal of dead bodies is one of the more important practices in the village area to make a healthy environment. This important practice for making healthy environment is done by only 24.00 per cent of the farmers bury the dead 
body of animals outside the village while 76.00 per cent farmers leave dead animals as such in open field. This study related to the disposal of animals' dead bodies is in agreement with Choudhary et al., (2017a).

Mostly 82.00 per cent were farmers measures adopted to control flies/mosquitoes by the help of producing smoke of waste grasses and 18.00 per cent not measure adopted against the control of flies and mosquitoes by use of an electric fan. This similar finding related to control flies support by Choudhary et al., (2017a), Khadda et al., (2017), Sabapara et al., (2015a). The present study revealed that 60.00 per cent of the farmers were controlled manually of measures adapted to control ticks and mites followed by 40.00 per cent of farmers control ticks and mites by using a dusting of insecticide. Khadda et al., (2017) and this study control ectoparasites manually highly contradicted by Choudhary et al., (2017a),

The result indicated that all the farmers treated their buffaloes for anestrous, repeat breeding, and sometimes infertility problem. It was found that 81.50 farmers treated the anoestrus and 18.50 per cent of farmers not treated their animals in the villages. This similar study related to the treatment of repeat breeding agreement with Sivaji et al., (2018).

In conclusion the village farmers of the Kanpur Nagar did not know importance of proper vaccination and deworming. They have lack of knowledge related to better care and management of the buffalo. Farmers should not aware for mastitis control, and disposal of dead animals.

\section{References}

Bhagat R. L., Phadke N. L., Potdar V., Swaminathan M., Singh P. K. and Tantia M. S. (2019) Management of
Lesser Known Kathani Cattle of Vidarbha Region. INTERNATIONAL JOURNAL OF TROPICAL AGRICULTURE, 37(2): 171-179.

20th Livestock Census (2019) Department of Animal Husbandry \& Dairying releases. Ministry of Fisheries, Animal Husbandry \& Dairying.

Choudhary Shweta, Gurjar M.L., Choudhary Vikas, Meel Padma, Rohlan Kavita and Ganguly Subha (2017a) Study on cattle calf rearing and health care practices in relationship to herd size in non tribal area of Udaipur district of Rajasthan. Journal of Entomology and Zoology Studies 2017; 5(4): 546-549.

Chakravarthi M. Kalyana, Bharadwaja Dr. Marella, Kumar Kutty and Dr. Potu Ramesh Babu (2017). Extent of Adoption of Improved Animal Husbandry Practices by Dairy Farmers in Kadapa District of Andhra Pradesh. International Journal of Science, Environment and Technology, 6(5): $2815-2820$.

Divekar B.S., Trivedi M.M. and Dhami A.J. (2016). Adoption of Improoved Animal Husbandry Practices by Dairy Farmers of Kheda District in Gujrat. International Journal of Science, Environment and Technology, Vol. 5, No 6, 2016, 4268 - 4276.

Gaikwad S.V., Awaz H.B., Savita L. and S.G. Narwade (2019). Studies on Management Practices of Buffaloes in Marathwada Region. Bull. Env. Pharmacol. Life Sci., Vol 8 [4] March 2019: 38-43.

Godara Vikas, Singh Narender, Kumar Sushil and Robin (2017a). Calf Rearing Management Practices Followed in Rural Areas of Western Haryana, India. Int.J.Curr.Microbiol.App.Sci., $\quad$ 6(12): 2996-3000.

Godara V., Gulati Harish Kr., Singh Narender and Robin (2018b) Buffalo Breeding 
Management Practices Followed by Farmers of Western Haryana. J Krishi Vigyan, 6(2) : 13-16.

Golhar M., Gubbawar S.G., Atkare V.G., Bhosale and Paytil L. (2017). Feeding and management practices of followed by buffalo owners in Umred Tahsil of Nagpur District. Trend of biosciences 10 (35): 7441-7446.

Khadda B.S., Lata Kanak, Singh Brijesh and Kumar Raj (2017). Study of buffalo husbandry practices in rural area of central Gujarat in India, Buffalo Bulletin (January-March 2017) Vol.36 No.1: 75-87.

Kishore K., Mahender M. and Chaudhary Harikrishna (2013) A Study on Buffalo Management Practices in Khammam District of Aandra Pradesh. Buffalo Bulletin (June 2013) Vol. 32 No. 2; $97-$ 108.

Malsawmdawngliana R., and Rahman S., (2016) Management practices followed by the dairy farmers of Mizoram, India. Journal of Livestock Science, 7: Pg. No.220-225.

Mulgu Rajasekhar, Neeradi Rajanna and Mallam Mahender (2018). Housing and Health Care Management Practices of Dairy Farmers in Urban and Peri-urban areas of Telangana. Journal of Animal Research: v.8 n.3, p. 467-472.

Pata B.A., Odedra M.D., Savsani H.H., Ahlawat A.R., Patbandha T.K. and Odedara A.B. (2019). Breeding, Calf and Health Management Practices Opted by Buffalo Owners in Junagadh and Porbandar Districts of Gujarat: A Comparative Study. Int.J.Curr. Microbiol.App.Sci (2019) 8(3): 24262435.

Patel N.B., Kavad S.D., Rao T.K.S. (2014) Eco-friendly livestock management practices followed by tribal households of Narmada valley region of India. Journal of Applied and Natural Science
6 (2): 512-518.

Patel P.C., Sabapara G.P. and Sorathiya L.M. (2019b). Health care management practices followed by dairy animal owners in tribal areas of Gujarat. Indian J. Anim. Prod. Mgmt. Vol. 35 (1-2): 5458.

Reddy G.C.S., Jagdeeswara S., Anitha A. and Subrahmanyeswary B. (2017). Existing breeding, feeding and housing management practices followed by the milk producers in Guntur district of Andhra Pradesh. Indian J. Anim. Prod. Mgmt. Vol. 33 (1-2): 26-32.

Sabapara G.P., Fulsoundar A.B. and Kharadi V.B. (2015). Survey of Calf Rearing Practices Followed at Rural Dairy Farms in Surat District. Journal of Animal Research: v.5 n.2, p. 257-261.

Singh D., Singh B.P., Bharti Rita and Pordhiya K.I. (2019). A socio economic and socio-psychological appraisal of farmer producer organizations. The Pharma Innovation Journal 2019; 8(4): 686-689.

Singh Ram (2018). Existing Animal Husbandry Practices in Narmada District of Gujarat in India. International Journal of Animal Science and Technology. Vol. 2, No. 2 (2): pp. 23-29.

Sivaji D.V., Natchimuthu K., Ramkumar S., Sreekumar D., Ganesan R. (2018). A Study on Adoption of Buffalo Husbandry Practices in Guntur and Prakasam Districts of Andhra Pradesh. Res J. Chem. Environ. Sci. Vol 6 [3] June 2018: 35-39.

Snedecor G.W. and Cochran W.G. (1994) "Statistical methods," 8th Edition, Iowa State University Press, Ames,.

Terramoccia S, Bartocci S, Taticchi A, Di Giovanni S, Pauselli M, Mourvaki E, Urbani S, Servilli M (2013) Use of dried stoned olive pomace in the feeding of lactating buffaloes: effect on 
the quantity and quality of the milk produced. Asian Australas J Anim Sci 26(7):971-980.

Viswkarma, Singh Ruchi, Kushram Priyanka, Singh Sandeep Kumar and Sharma
Shivangi (2018). Existing status of buffalo husbandry practices in Jabalpur. The Pharma Innovation Journal; 7(2): 08-11.

\section{How to cite this article:}

Deepak Singh, Ved Prakash, P. K. Upadhyay, Narendra Kumar, Satendra Kumar and Vimal Kumar. 2021. Existing Health Care Management Practices by Farmers of Kanpur Nagar District of Uttar Pradesh, India. Int.J.Curr.Microbiol.App.Sci. 10(02): 599-605. doi: https://doi.org/10.20546/ijcmas.2021.1002.071 